\title{
Targeting Gene Combinations for Broad-spectrum Rust Resistance in Heat-tolerant Snap Beans Developed for Tropical Environments
}

\author{
Charles J. Wasonga \\ Department of Horticultural Sciences, Cornell University NYSAES, Geneva, NY 14456
}

Marcial A. Pastor-Corrales

U.S. Department of Agriculture, Agricultural Research Service, Beltsville Agricultural Research

Center, Beltsville, MD 20705

Timothy G. Porch

U.S. Department of Agriculture, Agricultural Research Service, Tropical Agriculture Research

Station, Mayagüez, PR 00680

Phillip D. Griffiths ${ }^{1}$

Department of Horticultural Sciences, Cornell University NYSAES, 314 Hedrick Hall, 630 W. North

Street, Geneva, NY 14456

AdDitional INDEX wORDs. high-temperature stress, common bean rust, breeding, eastern Africa

\begin{abstract}
Common bean rust disease (caused by Uromyces appendiculatus) and high temperatures (heat stress) limit snap bean (Phaseolus vulgaris) production in many tropical and temperate regions. We have developed snap bean lines combining broad-spectrum rust resistance with heat tolerance for tropical agroecosystems. Eight breeding populations were developed by hybridizing BelJersey-RR-15 and BelFla-RR-1 (each possessing the $U r-4$ and $U r-11$ rust resistance genes) and the heat-tolerant snap bean breeding lines HT601, HT603, HT608, and HT611. $F_{2}-F_{4}$ generations of the populations were evaluated under greenhouse conditions and selected for heat tolerance while simultaneously selecting for the rust resistance genes $U r-4$ and $U r-11$. Three heat-tolerant $F_{5}$ lines, which were homozygous for $U r-4$ and $U r-11$ genes, were selected together with a rust-resistant but heat-sensitive control. These and 12 cultivars adapted to different geographical regions were evaluated for their reaction to rust and yield at six contrasting field sites in eastern Africa and their response to high temperature verified in Puerto Rico. Rust incidence and severity was high at three of the trial sites in eastern Africa. Two of the 12 cultivars were resistant to rust at most of these sites, and three of the four breeding lines were resistant at all sites. The $\boldsymbol{U} \boldsymbol{r}-11$ gene effectively conferred rust resistance at all sites. Yield in Puerto Rico was strongly correlated $\left(R^{2}=0.71, P<0.001\right)$ with that of the hottest site in eastern Africa, highlighting the similarity in genotypic response to high temperatures at the two distinct sites. The newly developed rust-resistant and heat-tolerant breeding lines showed stable yield at the eastern Africa sites with contrasting mean temperatures compared with the cultivars presently grown in the region. Two of these lines, HT1 and HT2, were confirmed to be homozygous for $U r-4$ and $U r-11$ and with high heat tolerance under both greenhouse and field environments. This research validates the effectiveness of targeted rust resistance gene combinations for tropical environments and the effective selection of high temperature tolerance traits correlating across multiple environments. The breeding lines HT1 and HT2 developed in this research could be used to improve snap beans for the tropics and other environments with similar constraints.
\end{abstract}

Common bean (Phaseolus vulgaris) is the most important legume grown for direct human consumption (Singh, 1999). It is cultivated principally for its dry seeds, green shelled seeds, and immature green pods, called snap beans. Snap beans are grown extensively in temperate regions for fresh market and processing and also in tropical and subtropical regions. In eastern Africa, snap beans is an important source of income for

Received for publication 16 July 2010. Accepted for publication 8 Sept. 2010 We are grateful for the support of the Cornell Assistantship for Horticulture in Africa (CAHA), Towards Sustainability Fund (TSF), the Bradfield Research Award, and the Einaudi International Research Travel Grant of Cornell University for funding the study. The excellent field support provided by KARI (Kenya Agricultural Research Institute)-Kitale Regional Research Center, Homabay Farmers Training Center in Kenya and the World Vegetable Center-Regional Center for Africa in Arusha, Tanzania is highly appreciated. ${ }^{1}$ Corresponding author. E-mail: pdg8@cornell.edu. growers in countries, including Kenya, Tanzania, Uganda, and Sudan (Centro Internacional de Agricultura Tropical, 2006).

Common bean rust, caused by the basidiomycete fungus Uromyces appendiculatus, is a destructive disease of dry and snap beans worldwide and is a particularly endemic and severe disease in eastern and southern Africa (Kimani et al., 2002; Liebenberg, 2003; Wortmann et al., 1998). Yield loss attributed to bean rust ranges from $18 \%$ to $100 \%$ and damage is particularly high in humid and tropical areas, where severe epidemics are frequent (Liebenberg, 2003; Stavely and Pastor-Corrales, 1989). Snap bean cultivars with targeted resistance gene combinations to protect crops against common bean rust could reduce or eliminate the heavy dependence on fungicides while simultaneously lowering production costs and improving crop quality.

Although genetic resistance is a cost-effective, practical, and environmentally sound strategy for managing bean rust, effective resistance over time and space has been difficult to achieve 
as a result of the high virulence diversity in $U$. appendiculatus (Stavely and Pastor-Corrales, 1989). The bean rust pathogen is highly variable with more than 300 strains, known as races, that differ in virulence (Araya et al., 2004; Mbaga et al., 1996; Pastor-Corrales, 2001). As a result of the high virulence diversity of the bean rust, bean cultivars that are resistant in one location or year may be susceptible in another. Moreover, resistance conferred by single resistance genes has often failed as a result of the appearance of new races of the bean rust. For instance, appearance of new races of the rust pathogen has recently been reported in Michigan (2007) and North Dakota (2008) (Markell et al., 2009; Pastor-Corrales et al., 2010; Wright et al., 2008). Effective genetic resistance strategies to manage bean rust should therefore aim to combine multiple rust resistance genes to provide a broader and longer lasting or more durable resistance (Pastor-Corrales, 2006; Pastor-Corrales et al., 2007).

Genetic variation within the common bean rust pathogen mirrors the genetic variation for resistance in common bean. There are nine rust resistance genes that have been identified, characterized, and named (Liebenberg et al., 2006). These rust genes are dominant and are grouped into $U r-4, U r-6, U r-9$, $U r-12$, and $U r-13$, which originate from beans of the Andean gene pool and $U r-3, U r-5, U r-7$, and $U r-11$ from the Middle American gene pool (Pastor-Corrales et al., 2007; Steadman et al., 2002). The $U r-3, U r-4, U r-5, U r-6$, and $U r-11$ genes provide resistance to $44,30,70,22$, and 89 races, respectively, of the 90 races maintained at the U.S. Department of AgricultureAgriculture Research Service (USDA-ARS), Beltsville Agricultural Research Center (BARC) (Pastor-Corrales, 2001). The $U r-11$ gene is the most effective of all rust resistance genes known and is susceptible only to the Middle American $U$. appendiculatus Race 108 from Honduras (Pastor-Corrales et al., 2007). The Guatemalan PI 181996, which is one of the original sources of $U r$ - 11 , was resistant to all of $\approx 250$ different isolates of the rust pathogen from eastern and southern Africa (Liebenberg, 2003). The Ur-11 gene is also found in PI 151385 (Stavely and McMillan, 1991). The Andean Ur-4 resistance gene, susceptible to many known Andean races of the rust pathogen, is resistant to Race 108 that overcomes $U r-11$ and many other Middle American races (Pastor-Corrales, 2006). The combination of $U r-4$ and $U r-11$ genes provide resistance to all races of the pathogen maintained at BARC (Pastor-Corrales et al., 2007).

Within the cropping systems of eastern Africa, common bean genotypes from Andean and Middle America gene pools are grown, although the distribution of genotypes from these gene pools varies among countries (Asfaw et al., 2009; Wortmann et al., 1998). The growing of diverse common bean genotypes from the different gene pools has led to the development and proliferation of different races of the bean rust pathogen with which the bean genotypes coevolved at the centers of origin (Jochua et al., 2004; Liebenberg et al., 2006; Pastor-Corrales, 2006). Liebenberg (2003) reported the virulence diversity of some 248 isolates of the bean rust pathogen from various African countries.

Deployment of rust resistance genes to cultivars within different market classes of dry and snap beans to ensure sustainable management of the rust disease has remained a challenge as a result of the high diversity of common bean rust races coupled with the lack of information on prevalent races of the pathogen in many locations, including eastern Africa. A large number of bean genotypes previously improved with single rust resistance genes for resistance to rust have not remained resistant across all sites and seasons. Most snap bean cultivars grown in eastern and southern African countries are a result of susceptibility to rust (Hillocks et al., 2006; Jochua et al., 2004; Kimani et al., 2002). Although studies have shown that combinations of $U r-4$ and $U r-11$ rust resistance genes confer resistance against all known races of the rust pathogen in common bean, snap beans with the combination of these two genes have not been widely tested, documented, and adopted in eastern Africa.

Adding to the challenge of bean rust to snap bean production in many tropical environments is heat stress. Exposure of plants to heat stress reduces the yields and quality of many crops (Wahid et al., 2007). The adverse effects of heat stress on plant growth and productivity is of concern on a global scale in light of Intergovernmental Panel on Climate Change (IPCC) predictions that the average global atmospheric temperatures will rise $2.6^{\circ} \mathrm{C}$ by 2050 relative to 1990 and rise $5.8^{\circ} \mathrm{C}$ by 2100 (Challinor et al., 2007; IPCC, 2001). Many areas around the world presently experience periods of heat stress that coincide with cropping seasons and significantly reduce yields. The production of crops, including common bean, are being expanded into more marginal and warmer zones to meet nutritional needs of the world's growing human population (Porch et al., 2007).

In common bean, average maximum (day) and minimum (night) temperatures exceeding 30 and $20^{\circ} \mathrm{C}$, respectively, during reproductive development reduce yield (Rainey and Griffiths, 2005a). Heat stress affects pollen development and disrupts fertilization and ovule development in common bean, which leads to bud and flower abscission, development of deformed pods, and reduced pod number (Omae et al., 2007; Porch and Jahn, 2001). There is genetic variability in tolerance to heat stress within the common bean (Porch et al., 2004; Rainey and Griffiths, 2005b). Heat-induced abscission of reproductive organs, which is a major determinant of yield under heat stress in many annual grain legumes, is controlled by a single gene in common bean (Rainey and Griffiths, 2005a). Snap beans with tolerance to heat stress could increase productivity in existing high-temperature environments as well as expand production areas and/or enable production during higher temperature seasons of the year.

The agroecological zones in which snap beans are grown in eastern Africa are at present mostly restricted to high and midaltitudes where temperatures are cooler and to which current cultivars are well adapted. The altitude in these regions is typically over $1500 \mathrm{~m}$. At the lower and midaltitude regions, where temperatures are higher, particularly during nighttime, snap bean yield is low. Thus, high temperatures constrain a large number of farmers in the warmer environments from effectively engaging in the production of snap beans.

The combined challenges that common bean rust disease and high temperatures pose to snap bean production in places such as eastern Africa require a better understanding of the trait responses and combinations and development of cultivars with the ability to perform effectively under these two stresses. The objectives of this research were: 1 ) to develop and evaluate snap bean populations that combine the $U r-4$ and $U r-11$ rust resistance genes with heat tolerance; 2) to select from subsequent generations of these populations breeding lines that combine rust resistance (based on the $U r-4$ and $U r-11$ gene combination) and heat tolerance in the same genetic background; and 3) to 
evaluate the selected breeding lines with combinations of the two traits at contrasting field sites in eastern Africa and to verify their performance in a high-temperature environment in Puerto Rico.

\section{Materials and Methods}

Plant materials and population development. Two USDA-ARS-BARC bean breeding lines, BelFla-RR-1 and BelJersey-RR-15, both of which have the $U r-4$ and $U r-11$ rust resistance genes, were used as sources of resistance. BelFlaRR-1 (BF) is a fresh-market bush-type green bean with the $U r-11$ gene introgressed from PI 151385 and the $U r-4$ gene from 'Early Gallatin'. BelJersey-RR-15 (BJ) is a processing bush-type green bean with the $U r-11$ gene introgressed from PI 181996 and the Ur-4 gene from 'Early Gallatin'. Both BF and BJ also have the $I$-gene for bean common mosaic virus resistance. Four snap bean breeding lines, HT601, HT603, HT608, and HT611, were used as sources of heat tolerance. The heat-tolerant lines were developed at Cornell University, Geneva, NY (Rainey and Griffiths, 2004, 2005c). The four heat-tolerant parents were early-maturing and had a bush-type growth habit with fleshy, straight, long, and smooth textured pods concentrated in set at the upper two-thirds of the canopy.

Eight populations were developed in Mar. and Apr. 2007 from crosses involving the two rust-resistant lines (BF and BJ) with the four heat-tolerant lines (HT601, HT603, HT608, HT611). The parents were crossed using a hooking method without emasculation (Bliss, 1980). The crosses made were: HT601 × BJ, HT603 × BF, HT608 × BF, BF $\times$ HT601, BF $\times$ $\mathrm{HT} 611, \mathrm{BJ} \times \mathrm{HT} 608, \mathrm{BJ} \times \mathrm{HT} 611$, and BJ $\times$ HT603. Eight $\mathrm{F}_{1}$ hybrids were self-pollinated and subsequent generations of each of the eight populations were evaluated for rust resistance or yield components under heat stress in greenhouse comparisons.

Selection for heat TOLERANCE. Selection for heat tolerance was done at the $\mathrm{F}_{2}$ and $\mathrm{F}_{3}$ generations. Eight populations were evaluated at the $\mathrm{F}_{2}$ generation. For each of the $\mathrm{F}_{2}$ populations, 48 plants were grown under heat stress for preliminary selection of plants under high-temperature conditions. Eight checks that included the six parents BF, BJ, HT601, HT603, HT608, and HT611 and two snap bean cultivars, Hystyle (Harris Moran, Modesto, CA) and Juliet (Alpha Seeds, Henley on Klip, South Africa), were used during the $\mathrm{F}_{2}$ evaluation. Eight plants were grown for each of the eight checks. Two seeds (later thinned to one plant after germination) were planted on 7 Oct. 2007 in 20-cm-diameter, 20-cm-deep round plastic pots filled with "Cornell mix" growth medium (Boodley and Sheldrake, 1972). Sets of plants of each of the eight populations and checks were randomly assigned to separate benches within the greenhouse in a completely randomized design. The plants were uniformly irrigated throughout the period of the greenhouse trial. Plants were staked and tied to ensure upright growth within the pots. Greenhouse temperature was maintained at $24 / 21{ }^{\circ} \mathrm{C}$ (day/night) for the first 3 weeks after which it was raised and maintained at $32 / 27^{\circ} \mathrm{C}$ (day/night) until the end of the crop cycle to ensure heat stress started several days before anthesis.

The $\mathrm{F}_{2}$ plants were visually selected for pod set, pod quality, and growth habit. The yield component data collected at harvest included pod number per plant, seed weight per plant (in grams), seed number per plant, seeds per pod, and single seed weight (in grams). Single-seed weight was recorded to guide selection for pod size, because seed weight and pod size are highly correlated. Fifty-five selections were made from the eight $F_{2}$ populations.

At the $F_{3}$ generation, five progeny from each of the 55 selections were evaluated in Feb. 2008 under high-temperature stress as described for the $\mathrm{F}_{2}$ experiment. For the $\mathrm{F}_{3}$ heat evaluation, the genotypes used as checks included 'Bronco' (Seminis, St. Louis, MO), 'CT70' (Cornell University, Geneva, NY), 'HB1880' (Syngenta, Boise, ID), 'Masai' (Syngenta), 'Spartacus' (Seminis), 'Venture' (Syngenta), and those used in the $F_{2}$ screen. Twenty-one breeding lines derived from additional crosses were also evaluated. A total of 90 genotypes was evaluated at the $F_{3}$. Plants were randomized throughout the greenhouse and maintained as previously described.

To arrive at the final selections at the $\mathrm{F}_{2}$ and $\mathrm{F}_{3}$ generations, means of four yield components, pod number per plant, seed number per plant, seed number per pod, and seed weight per plant (in grams), were independently ranked and mean rankings calculated for each of the genotypes. For each of the yield components, the genotypes tested were ranked in ascending order starting with the genotype with the highest value of the yield component in question. The averaging of the ranks of the four yield components giving equal weight to each minimizes possibilities of inaccuracies that may arise from selections based on only a single yield component. For instance, selections based only on pod number per plant may not accurately reflect tolerance to heat stress because some genotypes have the ability to form many pods under hot conditions but form fewer seeds, which may in addition have lower single seed weight and lower seed viability.

Selection FOR RUST RESistance. All the $55 \mathrm{~F}_{3}$ lines previously selected for tolerance to heat stress at the $F_{2}$ and reevaluated for heat tolerance at the $F_{3}$ were tested at the $F_{4}$ generation for homozygosity of two dominant rust genes, $U r-4$ and $U r-11$. To evaluate the lines for the two rust genes, bean seedlings were inoculated with Races 67 and 108 of the bean rust pathogen under greenhouse conditions at USDA-ARSBARC. Five checks were included in the rust evaluation: 'Pinto 114' (University of Idaho, Kimberly, ID) with no known rust resistance genes and susceptible to Races 67 and 108; 'Early Gallatin' (Gallatin Valley, Twin Falls, ID) with Ur-4 and susceptible to Race 67 and resistant to Race 108; PI 181996 with $U r-11$ and resistant to Race 67 and susceptible to Race 108; and the snap bean breeding lines BF and BJ, both with $U r-4$ and $U r-11$ and both resistant to Races 67 and 108. The inoculations were conducted between 6 May and 18 June 2008. Additional inoculations with rust Races 49 and 108 to identify $U r-4$, Race 47 to identify $U r-5$, and Race 67 to identify $U r-11$ were done in Aug. 2009 to determine the status (with respect to these three rust resistance genes) of selected snap bean cultivars used as checks during field trials.

To distinguish the reaction of the breeding lines to the races of the bean rust pathogen, primary leaves of each 7-d-old bean seedling inoculated with Race 67 were cut at the tip, whereas the leaf inoculated with Race 108 was left intact. The inoculum (urediniospores), at a concentration of 60,000 spores $/ \mathrm{mL}$, was dispersed in water using polysorbate 20 . To promote pathogen development, inoculated plants were placed in the dark in a Percival dew chamber (Geneva Scientific, Fontana, WI) set at $19{ }^{\circ} \mathrm{C}$ and programmed to deliver very light dew that resulted in a relative humidity of $\approx 95 \%$. The plants were incubated in the dew chamber for $16 \mathrm{~h}$ and then moved to a greenhouse where they were kept for $14 \mathrm{~d}$ before the host reaction was recorded. For each of the lines, 14 plants were scored for rust and those 
without rust symptoms were assumed to be fixed (homozygous) for the two rust genes and were selected.

Pustule size and type on the foliage were visually evaluated using the standard grading scale of 1 to 6 for rust evaluation (Stavely et al., 1983). The grading scale was as follows: $1=$ leaves without any visible rust symptoms; $2=$ leaves with necrotic spots without sporulation; $2^{+}=$necrotic spots 0.3 to 1 $\mathrm{mm}$ in diameter; $2^{++}=$necrotic spots 1 to $3 \mathrm{~mm}$ in diameter; $3=$ tiny pustules (uredinia) less than $0.3 \mathrm{~mm}$ in diameter; $4=$ uredinia 0.31 to $0.5 \mathrm{~mm}$ in diameter; $5=$ uredinia 0.51 to 0.8 $\mathrm{mm}$ in diameter; and $6=$ uredinia larger than $0.8 \mathrm{~mm}$. Plants with a grade of 1 to 3 (pustules absent, necrotic spots without sporulation, or tiny sporulating pustules with diameters under $0.3 \mathrm{~mm}$ ) were considered resistant, whereas those with large sporulating pustules with grades of 4 or higher were considered susceptible. The resistance reaction conditioned by the $U r-4$ rust gene in response to Race 108 or to any other race of common bean rust in which $U r-4$ conditions resistance is expressed as necrotic non-sporulating spots (referred to as Grades $2,2^{+}, 2^{++}$), also known as the hypersensitive response. The resistant reaction of the $U r-11$ rust gene to Race 67 , or to any other race to which $U r-11$ is resistant, is expressed as faint necrotic non-sporulating spots accompanied by a few tiny sporulating uredinia (rust pustules) that is referred to as Grade 3. The susceptible reactions of $U r-4$ and $U r-11$ are expressed as large or very large sporulating uredinia classified as Grades 4 to 6.

Of the $55 \mathrm{~F}_{3}$ snap bean breeding lines that were tested for rust resistance at the $\mathrm{F}_{4}, 15$ were confirmed to be homozygous for the $U r-4$ and $U r-11$ genes (Table 1). From the 15 breeding lines that were fixed for the $U r-4$ and $U r-11$ rust resistance genes, three lines that also ranked high for heat tolerance were selected. The three selected breeding lines were (601BJ)L9, (BF601)L4, and (BF611)L11 (Table 1).

Design of field trials in eastern Africa and Puerto Rico. The three selected rust-resistant and heat-tolerant breeding lines (601BJ)L9 (HT2), (BF601)L4 (HT1), and (BF611)11 (HT3) were evaluated together with a rust-resistant but heatsensitive control, (601BJ)L4 (HS1) (Table 1), and an additional set of 12 cultivars grown in different geographical regions. 'Amy' (Seminis), 'PV 712' (Pop Vriend, Andijk, The Netherlands), 'Teresa' (Seminis), and 'PV 698' (Pop Vriend) are currently grown in eastern Africa; 'Barrier' (Alpha Seeds) and 'Juliet' (Alpha Seeds) are grown in southern Africa; 'Palati' (Syngenta) is grown in northern Africa; 'Opus' (Seminis) and 'Brio' (Seminis) are grown in the southern United States; and 'Bronco' (Seminis), 'Hystyle' (Harris Moran), and 'Masai' (Syngenta) are grown in the northeastern United States. Seed for the field evaluation was increased in a climate-controlled greenhouse with temperatures maintained at $24 / 21{ }^{\circ} \mathrm{C}$ (day/ night). Seeds were coated with the fungicide captan (Bayer Crop Science, Cary, NC) to satisfy seed import requirements and to enable a more uniform stand.

The trials were laid out in a randomized complete block design with four replicates at sites in eastern Africa and with five replicates in Puerto Rico. Six sites were planted in eastern Africa, five in Kenya, and one in Tanzania and one site in Juana Diaz, PR. For every replicate, a single row plot measuring $2.5 \mathrm{~m}$ in length was planted with 25 plants of each of the 16 genotypes. A planting density in which single plants were planted at a spacing of $0.5 \mathrm{~m}$ between rows in the sites in Africa and $1 \mathrm{~m}$ between rows in Puerto Rico and 0.1-m seed spacing within rows at all locations was adopted.

Table 1. Mean values and rankings $(\mathrm{R})$ of four yield components in $15 \mathrm{~F}_{3}$ snap bean breeding lines determined to be homozygous for $U r-4$ and $U r$ 11 bean rust resistance genes and a subset of five control cultivars (Bronco, Spartacus, Juliet, Venture, and Masai) in a trial where 90 snap bean genotypes were evaluated in a greenhouse under high temperature conditions, $32 / 27^{\circ} \mathrm{C}$ (day/night).

\begin{tabular}{|c|c|c|c|c|c|c|c|c|c|}
\hline \multirow[b]{2}{*}{ Genotype } & \multicolumn{2}{|c|}{ Seeds/plant (no.) } & \multicolumn{2}{|c|}{ Seeds/pod (no.) } & \multicolumn{2}{|c|}{ Pods/plant (no.) } & \multicolumn{2}{|c|}{ Seed wt (g/plant) } & \multirow{2}{*}{$\begin{array}{c}\text { Average } \\
\text { rank }\end{array}$} \\
\hline & Value $^{z}$ & Rank & Value & Rank & Value & Rank & Value & Rank & \\
\hline$(\mathrm{BF} 601) \mathrm{L} 4$ & $72.4 \mathrm{a}-\mathrm{k}$ & 13 & $4.6 \mathrm{a}-\mathrm{d}$ & 5 & $16.0 \mathrm{a}-1$ & 32 & $14.5 \mathrm{a}-\mathrm{e}$ & 6 & 14.0 \\
\hline (BF611)L11 & $66.8 \mathrm{a}-\mathrm{m}$ & 20 & $4.1 \mathrm{a}-\mathrm{h}$ & 17 & $16.4 \mathrm{a}-\mathrm{k}$ & 29 & $13.2 \mathrm{a}-\mathrm{i}$ & 16 & 20.5 \\
\hline (BF611)L2 & $58.3 \mathrm{a}-\mathrm{n}$ & 38 & $4.4 \mathrm{a}-\mathrm{f}$ & 8 & $13.3 \mathrm{~b}-1$ & 62 & $12.1 \mathrm{a}-\mathrm{j}$ & 26 & 33.5 \\
\hline (BJ603)L3 & $56.0 \mathrm{a}-\mathrm{n}$ & 43 & $3.6 \mathrm{a}-\mathrm{n}$ & 53.5 & $15.6 \mathrm{a}-1$ & 37 & $11.9 \mathrm{a}-\mathrm{j}$ & 30 & 40.9 \\
\hline (BF611)L7 & $48.0 \mathrm{c}-\mathrm{n}$ & 59.5 & $3.4 \mathrm{a}-\mathrm{O}$ & 61.5 & $14.3 \mathrm{a}-1$ & 51 & $11.1 \mathrm{a}-\mathrm{j}$ & 36 & 52.0 \\
\hline$(\mathrm{BJ} 611) \mathrm{L} 1$ & $46.8 \mathrm{c}-\mathrm{n}$ & 65.5 & $4.2 \mathrm{a}-\mathrm{h}$ & 11 & $11.0 \mathrm{e}-1$ & 74.5 & $6.7 \mathrm{e}-\mathrm{k}$ & 77 & 57.0 \\
\hline Juliet & $57.4 \mathrm{a}-\mathrm{n}$ & 40 & $3.1 \mathrm{c}-\mathrm{O}$ & 75 & $14.2 \mathrm{a}-1$ & 54 & $7.1 \mathrm{c}-\mathrm{k}$ & 75 & 61.0 \\
\hline Venture & $37.4 \mathrm{e}-\mathrm{n}$ & 77 & $4.2 \mathrm{a}-\mathrm{g}$ & 11 & $9.0 \mathrm{i}-1$ & 87 & $6.1 \mathrm{~g}-\mathrm{k}$ & 84 & 64.8 \\
\hline (BF601)L6 & $36.3 \mathrm{e}-\mathrm{n}$ & 79 & $3.6 \mathrm{a}-\mathrm{n}$ & 50 & $10.3 \mathrm{f}-1$ & 80.5 & $8.3 \mathrm{~b}-\mathrm{k}$ & 62 & 67.9 \\
\hline$(601 B J) L 4$ & $35.3 \mathrm{e}-\mathrm{n}$ & 80 & $3.4 \mathrm{a}-\mathrm{o}$ & 61.5 & $10.3 \mathrm{f}-1$ & 80.5 & $4.7 \mathrm{j}-\mathrm{k}$ & 88 & 77.5 \\
\hline$(603 \mathrm{BF}) \mathrm{L} 2$ & $28.81-\mathrm{n}$ & 86 & $2.2 \mathrm{~m}-\mathrm{o}$ & 88 & $12.5 \mathrm{c}-1$ & 64 & $7.3 \mathrm{c}-\mathrm{k}$ & 73 & 77.8 \\
\hline Masai & $20.8 \mathrm{n}$ & 90 & $2.5 \mathrm{k}-\mathrm{O}$ & 86 & 6.31 & 90 & $2.3 \mathrm{k}$ & 90 & 89.0 \\
\hline Mean & 49.3 & & 3.5 & & 13.3 & & 9.3 & & 53.4 \\
\hline
\end{tabular}

${ }^{\mathrm{z}}$ For each of the yield components columns, means (values) followed by the same letter were not significantly different according to Student's $t$ test $(P \leq 0.05, \mathrm{n}=5)$. The mean groupings and rankings (rank) shown are based on a total of 90 lines tested. 
LOCATION AND DESCRIPTION OF FIELD TRIALS. Field trials were undertaken between Mar. and June 2009 during the long rainy season at the sites in eastern Africa and from June to Sept. 2009 in Puerto Rico. The sites were selected on the basis of differences in soils and climate. Table 2 summarizes information on the locations, standard geographic coordinates, climatic conditions, and soil chemical properties at the sites of the trial. Altitude at the sites in eastern Africa ranged from $1172 \mathrm{~m}$ at Homabay to $1829 \mathrm{~m}$ at Kitale (Table 2). The field trial in Puerto Rico was conducted at the Experiment Station of the University of Puerto Rico in Juana Diaz, located in south central Puerto Rico and was the lowest of the sites at an elevation of $21 \mathrm{~m}$. The Puerto Rico site differed significantly from the others in terms of latitude, soil, and climatic conditions.

There were temperature differences between the sites in eastern Africa, especially during the Mar. to June 2009 period of the study (Table 2). Homabay, which was at the lowest altitude of the six sites, had temperatures exceeding those at the high altitude site at Kitale by $\approx 3{ }^{\circ} \mathrm{C}$ and was more stressful for common bean reproductive development. Arusha had the lowest mean temperatures as a result of cooling effects of nearby Mount Meru. Puerto Rico had the highest mean temperatures among the trial sites with mean daily temperatures of $22.9{ }^{\circ} \mathrm{C}$ (minimum) and $33.8{ }^{\circ} \mathrm{C}$ (maximum) during the period that coincided with the reproductive phase of development.

Soils at the sites differed in type, chemical properties, and fertility status (Table 2). Soil $\mathrm{pH}$ at the sites ranged from 4.7 to 7.3. Soils at Homabay were heavy clays, high in phosphorus (P) and potassium $(\mathrm{K})$ and moderate in nitrogen $(\mathrm{N})$ content, and were the most fertile of the sites. Soils at Arusha were also considered fertile and were neutral in $\mathrm{pH}$ and had the highest $\mathrm{K}$ content compared with the other sites.

The sites selected for this study included Kitale, which represented the cool highland regions where most snap bean production in eastern Africa is currently concentrated. The inclusion of lower altitude sites such as Homabay and Kibos (and verification in Puerto Rico) aimed at testing and documenting potential performance of the developed snap bean genotypes at higher temperature environments in eastern Africa where snap bean production is presently low as a result of poor cultivars.

The sites were tractor ploughed and harrowed to a fine tilth before planting. Planting in eastern Africa was undertaken in Mar. and Apr. 2009 at the onset of the rainy season, whereas in Puerto Rico, the planting was completed on 25 June 2009. A compound inorganic fertilizer containing $10 \mathrm{~N}-11.3 \mathrm{P}-8.3 \mathrm{~K}$ was row-applied at planting at a rate of $200 \mathrm{~kg} \cdot \mathrm{ha}^{-1}$ at all the sites in eastern Africa except Arusha where no fertilizer was applied because soils at the site were considered fertile. In Puerto Rico, inorganic fertilizer (containing 10N-4.4P-8.3K) was applied at 2 weeks after planting at a rate of $400 \mathrm{~kg} \cdot \mathrm{ha}^{-1}$. Furrow irrigation supplemented rainfall at Arusha, whereas the trial plots at the other eastern Africa sites were rain-fed. The site in Puerto Rico was drip-irrigated. Standard agronomic practices were followed in managing the trial plots. The trial plots were kept free of weeds through cultivation by hand.

Field DATA COLlection AND ANALYSis. Each of the entries was monitored for symptoms of rust and other diseases based on natural infection under field conditions. Dates on which first disease symptoms were observed at the sites were noted so as to

Table 2. Location, standard geographic coordinates, climatic, and soil chemical properties at six sites in eastern Africa and Puerto Rico where 16 snap bean genotypes were evaluated for yield and reaction to common bean rust during 2009 field trials.

\begin{tabular}{|c|c|c|c|c|c|c|c|}
\hline & \multicolumn{7}{|c|}{ Site } \\
\hline & Arusha & Homabay & Kibos & Kitale & Maseno & Sabatia & Puerto Rico \\
\hline Country & Tanzania & Kenya & Kenya & Kenya & Kenya & Kenya & Puerto Rico \\
\hline Altitude (m) & 1235 & 1172 & 1185 & 1829 & 1526 & 1583 & 21 \\
\hline Longitude & $36^{\circ} 49^{\prime} \mathrm{E}$ & $34^{\circ} 28^{\prime} \mathrm{E}$ & $34^{\circ} 49^{\prime} \mathrm{E}$ & $34^{\circ} 59^{\prime} \mathrm{E}$ & $34^{\circ} 36^{\prime} \mathrm{E}$ & $34^{\circ} 46^{\prime} \mathrm{E}$ & $66^{\circ} 13^{\prime} \mathrm{W}$ \\
\hline \multicolumn{8}{|c|}{ Rainfall (temperature) $\left[\mathrm{mm}\left({ }^{\circ} \mathrm{C}\right)\right]^{\mathrm{z}}$} \\
\hline March & $0(27)$ & $40(31)$ & $52(32)$ & $24(29)$ & $52(-)$ & $127(-)$ & - \\
\hline May & $53(23)$ & $211(28)$ & $103(29)$ & $142(26)$ & $103(-)$ & $123(-)$ & - \\
\hline June & $13(22)$ & $44(28)$ & $29(30)$ & $33(25)$ & $29(-)$ & $66(-)$ & - \\
\hline \multicolumn{8}{|l|}{ Soils $^{\mathrm{y}}$} \\
\hline $\mathrm{pH}\left(\mathrm{H}_{2} \mathrm{O}\right)$ & 7.3 & 5.5 & 5.2 & 5.3 & 4.7 & 5.0 & 7.1 \\
\hline Carbon (\%) & 2.9 & 2.1 & 0.4 & 1.2 & 1.1 & 1.2 & 1.0 \\
\hline Nitrogen $(\%)$ & 0.1 & 0.5 & 0.2 & 0.4 & 0.3 & 0.4 & 0.1 \\
\hline Manganese $\left(\mathrm{mg} \cdot \mathrm{kg}^{-1}\right)$ & - & 0.3 & 0.9 & 1.0 & 3.1 & 3.2 & 418.0 \\
\hline Copper $\left(\mathrm{mg} \cdot \mathrm{kg}^{-1}\right)$ & - & 2.6 & 0.8 & 1.6 & 5.4 & 11.4 & 7.8 \\
\hline Iron $\left(\mathrm{mg} \cdot \mathrm{kg}^{-1}\right)$ & - & 16.2 & 29.0 & 38.8 & 38.3 & 33.1 & 131.0 \\
\hline Zinc $\left(\mathrm{mg} \cdot \mathrm{kg}^{-1}\right)$ & - & 3.6 & 4.2 & 9.6 & 9.5 & 11.7 & 3.5 \\
\hline
\end{tabular}

${ }^{\mathrm{z}}$ Temperatures at Maseno and Sabatia were not recorded. Weather data are not presented for Puerto Rico where the trial was conducted between June and Sept. 2009.

${ }^{y}$ Soils within the study plots were randomly sampled at a depth of 0 to $30 \mathrm{~cm}$. The soil analytical values presented for nitrogen (N) and phosphorus (P) are total $\mathrm{N}$ and available $\mathrm{P}$, respectively. Micronutrient content in the soils at Arusha was not determined. 
account for possible site differences in rust severity and its effect on yield. The genotypes were scored for common bean rust at flowering (R6) and at pod filling (R8) developmental stages. To obtain information on genotypic reaction to rust, rust incidence data were obtained by counting the number of rust infected plants per plot, whereas rust severity was determined by the number of rust pustules formed per leaflet. The sets of rust incidence and severity data were used in a correlation analysis to obtain a simultaneous quantification of genotype differences in reaction to rust. In the correlation plot, genotypes that had no rust were considered highly resistant, whereas those with high rust incidence and severity were considered highly rust-susceptible. The genotypes that had high, moderate, or low rust severity on a few plants (low incidence) were assumed to be either partially rust-resistant or heterozygous for the rust resistance genes. Genotypic yield performance was estimated by the number of pods produced per plant. The total number of pods produced per plot was counted while excluding plants at the end of the rows and then divided by total number of plants examined.

The statistical model used in the data analysis was:

$$
\mathrm{y}_{\mathrm{ijk}}=\mu+\alpha_{\mathrm{i}}+\beta_{\mathrm{j}}+\alpha \beta_{\mathrm{ij}}+\varepsilon_{\mathrm{ijk}}
$$

where: $y_{i j k}=k$ th response at combination $(i, j) ; \mu=$ overall mean; $\alpha_{i}=$ main effect of genotype $i ; \beta_{j}=$ main effect of site $\mathrm{j}$; $\alpha \beta_{\mathrm{ij}}=$ genotype/site interaction effect; and $\varepsilon_{\mathrm{ijk}}=$ random error associated with kth response at combination (i,j).

The data were statistically analyzed using regression and correlation analysis, analysis of variance, and the Tukey's test and contrasts for separating means. Regression analysis was done to determine if the yield response of the genotypes when grown at the high-temperature site in Puerto Rico could predict/ confirm the response of the genotypes when grown at the hightemperature sites in eastern Africa. The statistical analyses were completed using JMP 8 software (SAS Institute, Cary, NC).

\section{Results}

GREENHOUSE EVALUATION AND SELECTION FOR RUST RESISTANCE AND HEAT TOLERANCE. Fifteen of the $55 \mathrm{~F}_{3}$ lines were found to be homozygous for $U r-4$ and $U r-11$. These lines had the typical reaction of common bean plants with the $U r-4$ and $U r-11$ genes when inoculated with Races 67 and 108. The 15 rust-resistant lines differed in their reaction to heat stress as shown by their mean rankings of four yield components (pod number per plant, seed number per plant, seed number per pod. and seed weight per plant) measured for each of the 90 genotypes evaluated (Table 1). Only five of the 15 rust-resistant lines were ranked among the top $50 \%$ of the 90 genotypes evaluated under heat stress. Three of the 15 rust-resistant lines were among the top $25 \%$ in the ranking of the 90 lines for heat tolerance and were selected as heat-tolerant. The three selected rust-resistant and heat-tolerant lines were HT1, HT2, and HT3 with mean rankings of 14, 7.3, and 20.5, respectively, among the 90 genotypes evaluated.

REACTION TO COMMON BEAN RUST UNDER FIELD CONDITIONS. High rust incidence and severity were observed at Arusha, Homabay, and Kitale. No rust was observed in Sabatia and Puerto Rico. No data were collected from the Kibos and Maseno site as a result of damage of trial plots. The Arusha site experienced a longer duration of lower temperatures compared with Kitale and Homabay (Table 2). The lower temperatures of 22 to $25^{\circ} \mathrm{C}$ at Arusha in April to June promoted development of rust early in the season and the conditions remained favorable for rust development until the end of the crop cycle. Rust symptom development at Arusha started $\approx 2$ weeks after planting, when the plants were at the second trifoliate leaf growth (V2) stage. At Kitale and Homabay, rust symptoms did not manifest until 6 weeks after planting when most of the genotypes were at the pod formation and pod-filling stages.

Similar trends in rust incidence on the 16 genotypes were observed across the three sites (Arusha, Homabay, Kitale), and genotypes differed significantly in the frequency of rust-infected plants (Fig. 1). Three of the four breeding lines, HT1, HT2, and HS1, all of which combine the $U r-4$ and $U r-11$ rust resistance genes, had no plants with visible rust symptoms at the three sites where common bean rust occurred. Approximately $25 \%$ of HT3 plants were infected with rust, indicating that this breeding line was not fixed for the targeted $U r-11$ gene. The cultivars PV 698 and PV 712, both of which have the Ur-11 rust resistance gene, had no rust at the three sites. The cultivars Amy, Barrier, Brio, Bronco, Hystyle, Juliet, Masai, and Opus showed rust on more than $60 \%$ of plants at each of the three sites indicating that they were susceptible to rust at these sites. Many of these genotypes
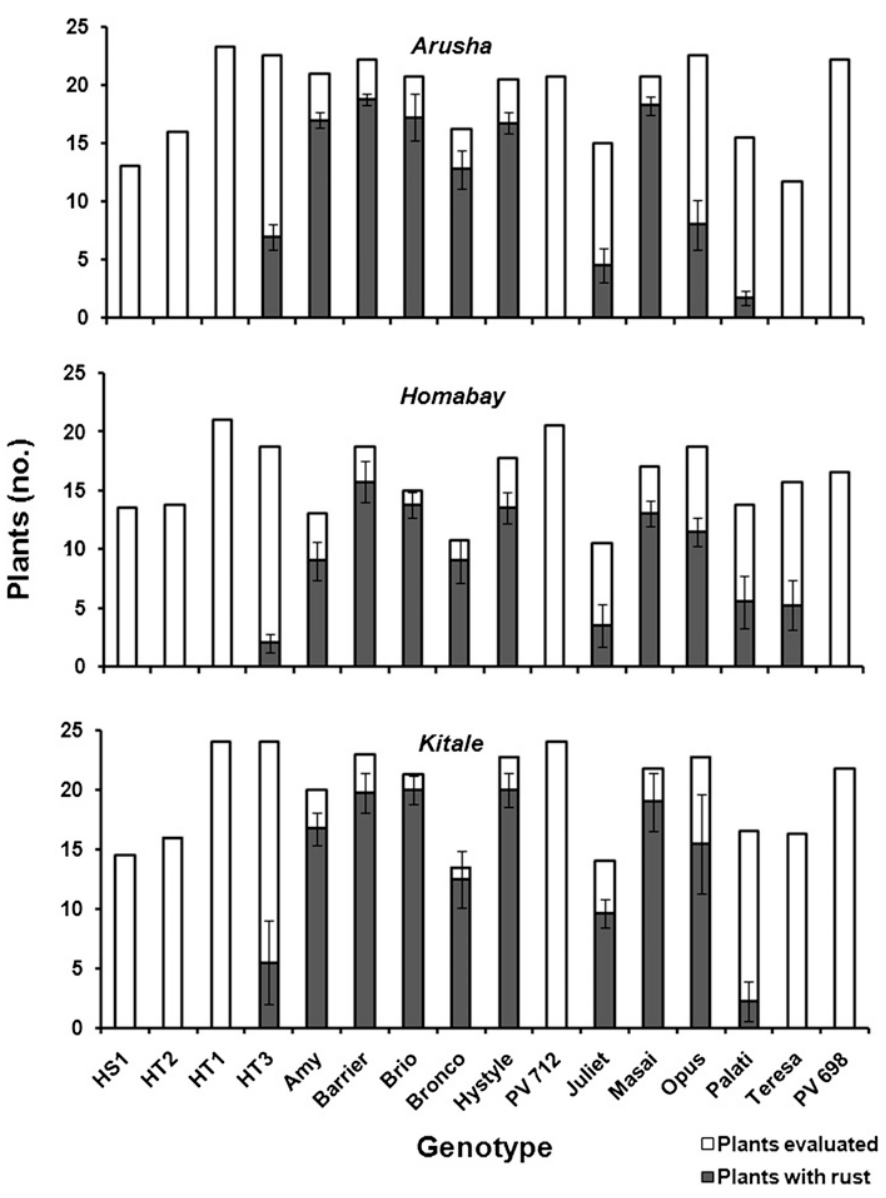

Fig. 1. Incidence of common bean rust on 16 snap bean genotypes evaluated at Arusha, Homabay, and Kitale sites in eastern Africa during 2009 field trials. HT1, HT2, and HT3 are breeding lines initially developed and selected as both rust-resistant and heat-tolerant. HS1 is a breeding line initially selected as rust-resistant but heat-sensitive and was included in the trial as a control. The remaining 12 genotypes are cultivars. The significance bars indicate SES $(n=4)$. 
have the $U r-4$ rust resistance gene, whereas others have no known rust resistance genes.

The genotypes differed significantly in rust severity, which ranged from absence of pustules on leaves to numerous pustules of different sizes observed on plant leaves (Fig. 2). The breeding lines HT1, HT2, and HS1 and the cultivars PV 698 and PV 712 were considered highly resistant because they had no visible rust pustules present at any of the three sites (Table 3; Fig. 3). 'Teresa' was also highly resistant at Arusha and Kitale but not at Homabay where some plants had rust symptoms, albeit with low severity (Table 3). Palati was also considered resistant, because only a small number of plants had small pustules. There was intense rust pustule formation on some Juliet plants indicating that the cultivar is heterogeneous for rust resistance. 'Amy', 'Barrier', 'Brio', 'Bronco', 'Hystyle', and 'Masai' were highly susceptible at all three rust-infected sites (Table 3). Very large pustules were also observed on the pods of 'Amy', 'Barrier', 'Brio', and 'Hystyle' at the Arusha site, confirming that these genotypes were highly susceptible to the bean rust pathogen. For the three sites combined, rust severity was highest in 'Amy' followed by 'Brio', 'Bronco', 'Barrier', 'Masai', and Hystyle' (Table 3).

Rust severity correlated with rust incidence and rust was more severe on genotypes that had the highest rust incidence (Fig. 3). The correlation between rust incidence and severity underscores the contribution of different rust resistance genes and gene combinations on snap bean genotype response to rust. Genotypes that had no known rust resistance genes, including 'Amy' and 'Masai', or only had the Ur-4 gene, including 'Opus', 'Brio', 'Barrier', 'Bronco', and 'Hystyle', had high rust incidence and severity (Fig. 3). The high rust incidence and severity observed on $U r-4$ genotypes indicates that this gene is not effective against the race(s) of the bean rust found at the three sites (Arusha, Homabay, Kitale).

'Teresa' and 'Palati', which have the Ur-5 rust resistance gene, were considered resistant to rust because they had low rust incidence and severity at the three sites (Table 3; Fig. 3). Effectiveness of the $U r-5$ gene was particularly notable at Kitale and Arusha, where there were no symptoms of rust on all 'Teresa' plants and no symptoms on $88 \%$ to $90 \%$ of 'Palati' plants, indicating that the $U r-5$ gene was effective against races of the rust pathogen at these sites (Fig. 1). The Ur-5 gene, which is of Middle American origin, has broad resistance against many races of the bean rust pathogen, especially races that are Andean in origin (Pastor-Corrales, 2006). Deployment of the $U r-5$ gene in cultivars targeted to regions where predominantly Andean beans are grown could increase the success rate of conferring resistance against the bean rust pathogen. However, the $U r-5$ conferred rust resistance in 'Teresa' and 'Palati' was not complete at the Homabay site where $\approx 30 \%$ of 'Teresa' plants and $42 \%$ of 'Palati' plants had mild rust symptoms (Fig. 1). This observation could be indicative of the possible presence, at the Homabay site, of a bean rust isolate that overcomes the $U r-5$ gene, although there was not $100 \%$ infection of the two cultivars with the $U r-5$ overcoming isolate.
Table 3. Severity of common bean rust on 16 snap bean genotypes evaluated at Arusha, Homabay, and Kitale sites and mean severity at the three sites combined during 2009 field trials in eastern Africa. ${ }^{\mathrm{z}}$

\begin{tabular}{lcccc}
\hline & \multicolumn{3}{c}{ Rust severity (pustules/leaflet) } \\
\cline { 2 - 5 } Genotype & Arusha & Homabay & Kitale & $\begin{array}{c}\text { Combined } \\
\text { sites }\end{array}$ \\
\hline HT1 & $0 \mathrm{~d}$ & $0 \mathrm{e}$ & $0 \mathrm{e}$ & $0 \mathrm{e}$ \\
HT2 & $0 \mathrm{~d}$ & $0 \mathrm{e}$ & $0 \mathrm{e}$ & $0 \mathrm{e}$ \\
HS1 & $0 \mathrm{~d}$ & $0 \mathrm{e}$ & $0 \mathrm{e}$ & $0 \mathrm{e}$ \\
HT3 & $62 \mathrm{a}-\mathrm{c}$ & $25 \mathrm{~b}-\mathrm{e}$ & $18 \mathrm{c}$ & $35 \mathrm{c}-\mathrm{e}$ \\
Opus & $26 \mathrm{a}-\mathrm{d}$ & $115 \mathrm{a}-\mathrm{e}$ & $42 \mathrm{bc}$ & $63 \mathrm{c}-\mathrm{e}$ \\
Palati & $16 \mathrm{~b}-\mathrm{d}$ & $16 \mathrm{~b}-\mathrm{e}$ & $8 \mathrm{c}$ & $13 \mathrm{de}$ \\
Hystyle & $37 \mathrm{a}-\mathrm{d}$ & $59 \mathrm{~b}-\mathrm{e}$ & $144 \mathrm{a}-\mathrm{c}$ & $80 \mathrm{~b}-\mathrm{d}$ \\
Barrier & $48 \mathrm{a}-\mathrm{c}$ & $177 \mathrm{ab}$ & $83 \mathrm{a}-\mathrm{c}$ & $103 \mathrm{a}-\mathrm{c}$ \\
PV 698 & $0 \mathrm{~d}$ & $0 \mathrm{e}$ & $0 \mathrm{e}$ & $0 \mathrm{e}$ \\
Amy & $57 \mathrm{a}-\mathrm{c}$ & $260 \mathrm{a}$ & $199 \mathrm{ab}$ & $172 \mathrm{a}$ \\
Juliet & $15 \mathrm{~cd}$ & $4 \mathrm{c}-\mathrm{e}$ & $33 \mathrm{bc}$ & $17 \mathrm{de}$ \\
Masai & $39 \mathrm{a}-\mathrm{d}$ & $153 \mathrm{a}-\mathrm{d}$ & $60 \mathrm{a}-\mathrm{c}$ & $84 \mathrm{~b}-\mathrm{d}$ \\
Brio & $64 \mathrm{ab}$ & $236 \mathrm{a}$ & $208 \mathrm{a}$ & $169 \mathrm{a}$ \\
PV 712 & $0 \mathrm{~d}$ & $0 \mathrm{e}$ & $0 \mathrm{c}$ & $0 \mathrm{e}$ \\
Teresa & $0 \mathrm{~d}$ & $27 \mathrm{~b}-\mathrm{e}$ & $0 \mathrm{c}$ & $9 \mathrm{e}$ \\
Bronco & $71 \mathrm{a}$ & $163 \mathrm{a}-\mathrm{c}$ & $197 \mathrm{ab}$ & $144 \mathrm{ab}$ \\
\hline
\end{tabular}

${ }^{\mathrm{z}} \mathrm{HT} 1$, HT2, and HT3 are breeding lines initially developed and selected as both rust-resistant and heat-tolerant. HS1 is a breeding line initially selected as rust-resistant but heat-sensitive and was included in the trial as a control. The remaining 12 genotypes are cultivars.

${ }^{\mathrm{y}}$ Site column genotype rust severity means not followed by the same letter(s) are not significantly different $(P \leq 0.05)$ according to Tukey's test.

'PV 698', which has the highly effective Ur-11 rust resistance gene and HS1, HT1, HT2, and 'PV 712' that have the $U r-4$ and $U r-11$ rust gene combination, were highly rustresistant and had no rust at the three sites. The observation that 


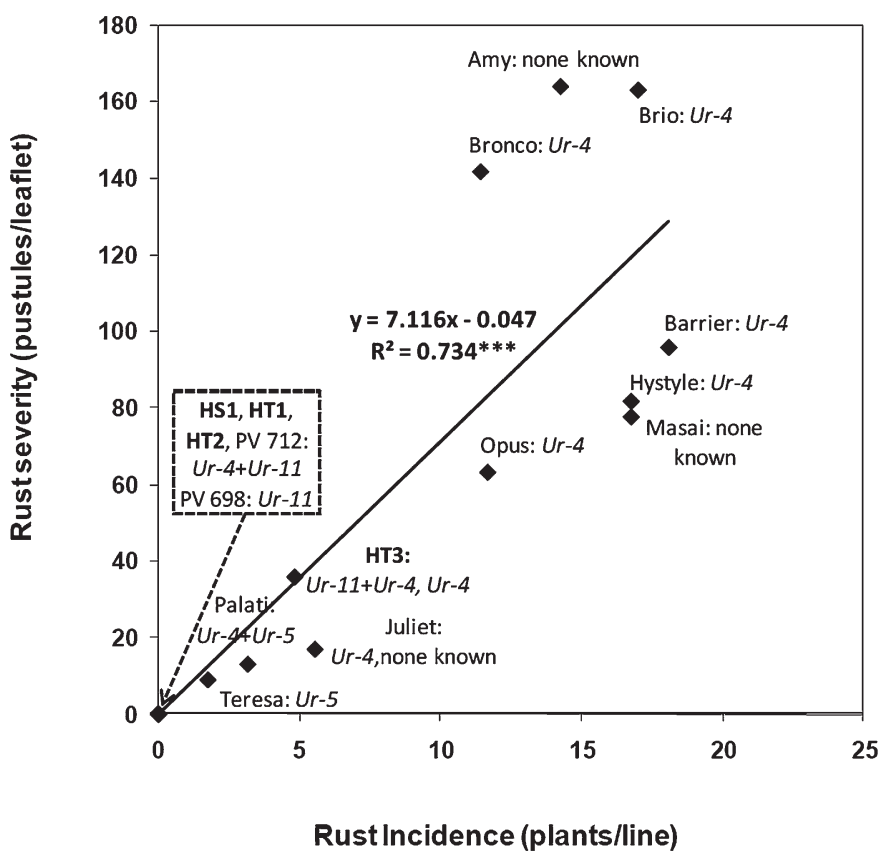

Fig. 3. Effect of different common bean rust resistance genes and gene combinations on rust disease incidence and severity on 16 snap bean genotypes evaluated at Arusha, Homabay, and Kitale sites in eastern Africa during 2009 field trials. HT1, HT2, and HT3 are breeding lines initially developed and selected as both rust-resistant and heat-tolerant. HS1 is a breeding line initially selected as rust-resistant but heat-sensitive and was included in the trial as a control. The remaining 12 genotypes are cultivars.
'PV 698' was rust-resistant at the sites indicates that the $U r-11$ gene conferred resistance against all races of the bean rust pathogen found at these sites and that the Middle American rust Race 108, which is known to overcome the $U r-11$ gene (PastorCorrales, 2006), was not present at the study sites.

Yield in eastern Africa And Puerto Rico. Yield data from Puerto Rico and for three eastern Africa field sites, Arusha, Homabay, and Kitale, were analyzed. In terms of performance of all the genotypes combined at each site, pod yield was highest at Kitale followed by Arusha and Homabay, which were not significantly different from each other, followed by Puerto Rico according to Tukey's test $(P \leq 0.05)$. The low yield at Puerto Rico indicates that it was the most stressful of the four sites.

Bean rust infection was the most important yield-influencing factor at Arusha, whereas at Homabay, yield was largely influenced by high-temperature stress and to a lesser extent by bean rust. Rust had less impact on yield at the Homabay site because rust symptoms did not appear until 6 weeks after planting when the bean genotypes were at the pod formation and podfilling stages. At the Puerto Rican site, high temperatures of $34 / 23{ }^{\circ} \mathrm{C}$ (day/night) during reproductive development resulted in significant symptoms of high-temperature stress, including bud, flower and pod abortion, poor pod fill, curved pods, and the excessive production of pin pods, thus significantly affecting yield response.

In a combined analysis of yield data from the sites, the breeding lines HS1 and HT2 were the highest yielding among the genotypes tested across the four sites, whereas 'PV 712', 'Masai', and 'Palati' had the lowest yields (Table 4). The high yields of the two breeding lines relative to the other genotypes tested underscores the contribution that the combined introgression of rust resistance and heat tolerance traits had in stabilizing performance of the breeding lines across the different sites.

Analysis of variance of yield from Arusha, Homabay, Kitale, and Puerto Rico sites combined revealed a highly significant genotype-by-site interaction effect $(P<0.001)$. The genotype-by-site interaction effect remained highly significant even when data from the sites in eastern Africa alone were analyzed in a combined analysis $(P<0.001)$. This significant interaction effect implies that factors influencing yield were unique to each of the sites and that they differentially affected genotypic performance. Given the uniqueness of the sites, genotypic performance at the four sites was interpreted on a site-by-site basis. At Arusha, where an early outbreak of the common bean rust was the most important yield-influencing factor, 'PV 698', 'Juliet', and the breeding line HT2 were the highest yielding, whereas the rust-susceptible cultivars, Brio, Bronco, and Hystyle, were the lowest yielding (Table 4). In Kitale, where there was a late-season bean 
rust outbreak and higher temperatures compared with Arusha but mild compared with Homabay, the highest yield was obtained from 'Teresa' followed closely by 'Masai', 'Bronco', 'Brio', and HT2, whereas the lowest yield was from 'Hystyle' (Table 4). At Homabay, where there was high-temperature stress and a lateseason rust outbreak, the highest yield was from HT2 followed by 'Opus', 'Hystyle', 'HS1', 'Bronco', and 'Brio' and the lowest yields were from 'PV 712' followed by 'PV 698', 'Masai', and 'Palati' (Table 4). In Puerto Rico, the highest yields were from HT2, 'Bronco', HS1, and 'Brio', whereas the lowest yields were from 'PV 698', 'PV 712', 'Amy', 'Juliet', and 'Masai' (Table 4). Pod yield of the rust-resistant and heat-tolerant breeding lines HT2, HS1, HT1, and HT3 ranked 1, 4, 5, and 6, respectively, out of the 16 genotypes evaluated in Puerto Rico (Table 4).

To understand how the different site conditions, including high rust pressure from an early-season outbreak at Arusha and high-temperature stress at Homabay and Puerto Rico, influenced genotypic performance, pod yield at the sites were compared using contrasts and regression analyses. Yield data from Arusha and Kitale were contrasted for selected rust-resistant and susceptible genotypes to test whether the difference in the duration of rust infection at the two sites significantly affected yield (Fig. 4). There was no significant yield difference between Arusha and Kitale sites for the highly rust-resistant genotypes, including HT1, HT2, and 'PV 712' (Fig. 4).

Among the highly rust-susceptible genotypes evaluated, two types of yield responses were observed between the early, or longer duration, rust-infected Arusha site and the late (or shorter duration) rust-infected site, especially Kitale. In the first response, yield was significantly reduced at the early rustinfected site at Arusha compared with the late rust-infected site at Kitale. The cultivars that manifested this yield response were Brio, Bronco, and Masai as the highly significant contrasts of their yields at these two sites illustrate (Fig. 4). The cultivars that showed this first type of yield response illustrate the magnitude of yield loss that a rust epidemic within snap bean

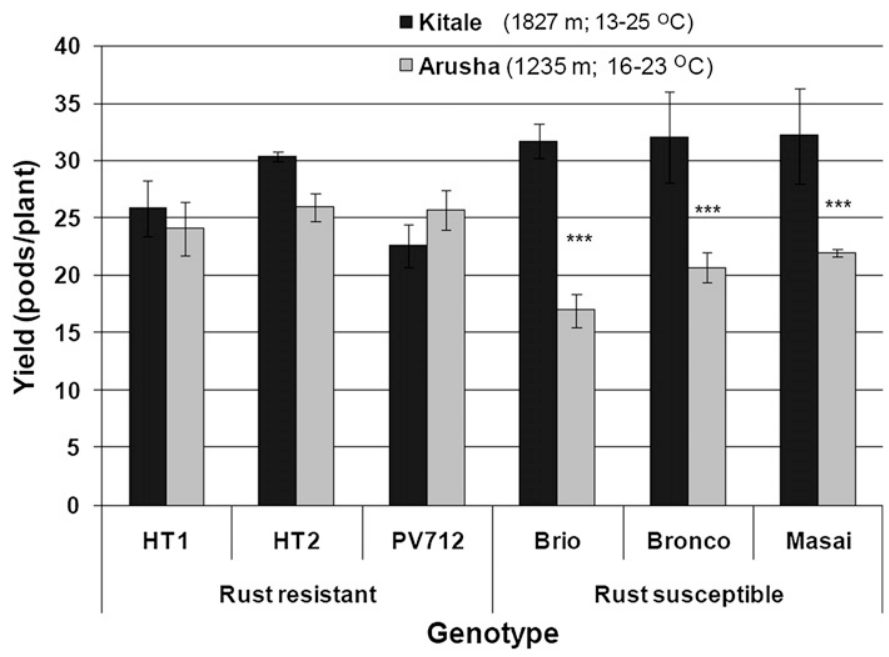

Fig. 4. Effect of early-season and late-season rust disease outbreak at Arusha and Kitale sites, respectively, on pod yield of rust-resistant and rustsusceptible snap bean genotypes evaluated during 2009 field trials in eastern Africa. HT1 and HT2 are breeding lines initially developed and selected as both rust-resistant and heat-tolerant, whereas PV712, Brio, Bronco, and Masai are cultivars. The bracketed figures appearing with the site legends respectively denote altitude and ranges of temperature during the period of the trial. Bars indicate $\mathrm{SE} ; * * *$ significant at $P \leq 0.001(\mathrm{n}=4)$. production regions may cause on susceptible cultivars depending on the stage in the crop growth cycle at which the disease begins. In the second yield response, in which the other highly susceptible cultivars Amy, Barrier, and Hystyle were grouped, there were no significant yield differences between the early and late rust-infected sites (Table 4). This second group of cultivars is considered rust-tolerant with respect to yield. However, there were large rust pustules on pods, which resulted in deformed pods and reduced quality even in these rusttolerant cultivars.

Yield data from Kitale and Homabay were contrasted for all the genotypes grown to test whether the difference in temperature at the two sites significantly affected yield and whether the newly developed breeding lines were tolerant to the temperature differences. Homabay and Kitale sites differ in both altitude and average temperature with Kitale being cooler and in the highlands and Homabay hotter and at a lower altitude. The effect of rust infection on yield at these two sites was assumed to be similar but minimal, because rust outbreak at both sites was late in the season. The pod yields of 'Amy', 'Teresa', 'PV 712', 'Masai', and 'PV 698' were significantly reduced at Homabay, whereas the yields of HT1 and HT2 did not significantly differ at the two sites (Fig. 5). The nonsignificant difference in yield of the breeding lines between the higher temperature and cooler temperature site in eastern Africa indicated that they were tolerant to the higher temperatures at least to the levels experienced at Homabay.

Regression analyses of data from the four sites revealed a strong positive correlation $\left(R^{2}=0.71, P<0.001\right)$ of pod yield of the 16 genotypes under high-temperature stress in Puerto Rico when compared with Homabay, the highest temperature African trial site (Fig. 6). There was a weak negative correlation of yield data between Puerto Rico and the Arusha site $\left(R^{2}=\right.$ $0.34, P=0.0188)$ and no correlation with the Kitale site $\left(R^{2}=\right.$ $0.03, P=0.525)$ (Fig. 6). The significant but weak negative correlation between Arusha and Puerto Rico yield data is attributed to contrasting responses of two sets of cultivars: 1)

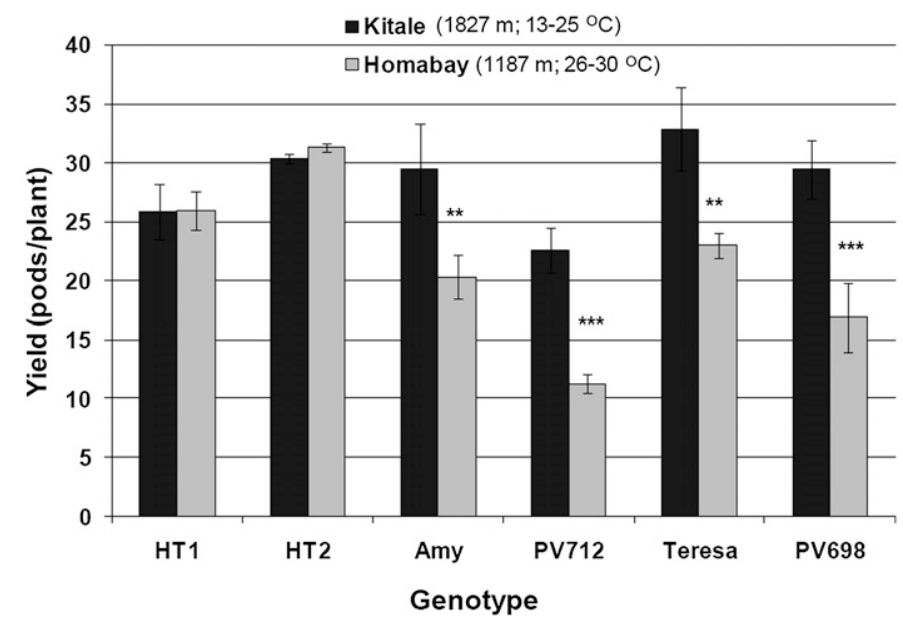

Fig. 5. Effect of temperature differences between Homabay and Kitale sites on pod yield of two rust-resistant and heat-tolerant snap bean breeding lines, HT1 and HT2, and four snap bean cultivars: Amy, PV 712, Teresa, and PV698 evaluated during 2009 field trials in eastern Africa. The bracketed figures appearing with the site legends, respectively, denote altitude and ranges of temperature during the period of the trial. Bars indicate $\mathrm{SE} ; * * *$ significant at $P<0.001, * * P \leq 0.01(\mathrm{n}=4)$. 

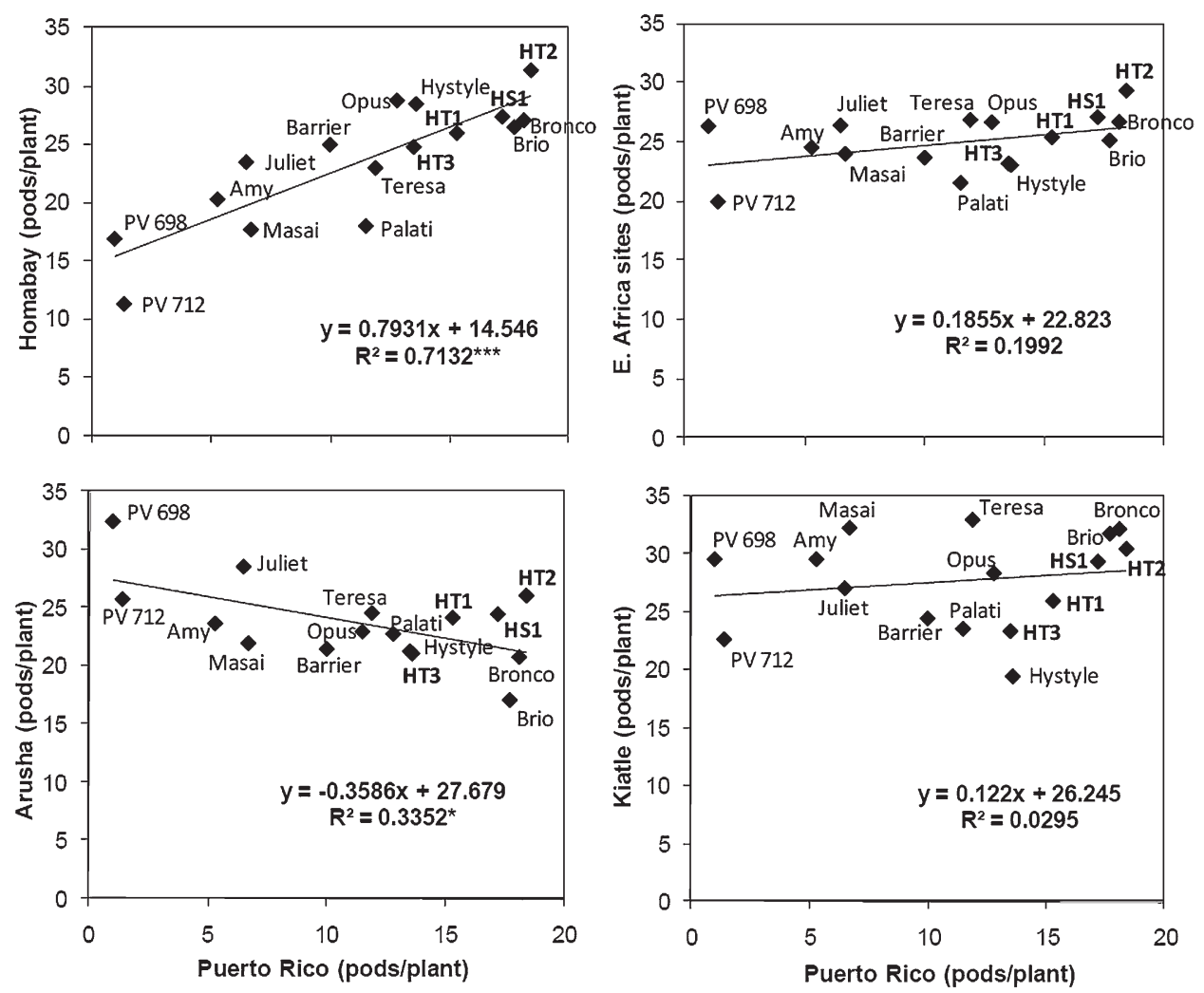

Fig. 6. Regression analysis of mean pod yield of 16 snap bean genotypes evaluated at three eastern Africa sites, Arusha, Homabay, and Kitale, and the eastern Africa sites combined with pod yield from Puerto Rico during 2009 field trials. HT1, HT2, and HT3 are breeding lines initially developed and selected as both rust-resistant and heat-tolerant. HS1 is a breeding line initially selected as rust-resistant but heat-sensitive and was included in the trial as a control. The remaining 12 genotypes are cultivars. The data points are means of four replicates for the eastern Africa sites and five replicates for the Puerto Rico site. $R^{2}$ values followed by $*$ and $* * *$ indicate statistical significance at $P \leq 0.05$ and $P \leq 0.001$, respectively. The highly significant $R^{2}$ value between Homabay and Puerto Rico indicates similarity in differential response of the genotypes to high temperatures at the two sites.

PV 698 and PV 712, which are rust-resistant and heat-sensitive and yielded well in Arusha but poorly in Puerto Rico; and 2) Brio and Bronco, which are rust-susceptible but heat-tolerant, yielded well in Puerto Rico and poorly in Arusha (Fig. 6). The contrasting response of these two sets of genotypes contributed significantly to the observed negative correlation.

At the Homabay and Puerto Rico sites 'Amy', 'Masai', 'PV 698', and 'PV 712' were the lowest yielding, whereas HT2, 'Bronco', HS1, and 'Brio' were among the highest yielding with HT2 having the highest yield at both sites (Table 4; Fig. 6). The highly significant correlation of the results for Homabay and Puerto Rico indicate that the high temperatures at the two sites similarly influenced genotype response across two very distinct agroecological zones. The lowest yielding genotypes at the two sites were therefore the most heat-sensitive, whereas the highest yielding genotypes were the most heat-tolerant. This observation confirmed that the genotype difference in yield responses at Homabay and Kitale was the result of site temperature differences.

\section{Discussion and Conclusions}

This research has successfully combined effective resistance to common bean rust involving the $U r-4$ and $U r-11$ rust resistance genes and tolerance to heat stress in a snap bean genetic background. The introgression of the two traits into a similar snap bean genetic background completed in this research is unique and innovative and is the first documented effort to address the challenge created by the cooccurrence of rust disease and heat stress across snap bean production environments. This study further documented a comparison of the performance of the rust-resistant and heat-tolerant snap bean breeding lines with commercial snap bean cultivars grown in the eastern Africa region through trials carried out at contrasting field sites in Kenya and Tanzania.

Results from the present study show stable rust resistance in three of the snap bean breeding lines, HS1, HT1, and HT2 with combinations of the $U r-4$ and $U r-11$ rust resistance genes, at three distinct field sites in Kenya and Tanzania. The results obtained with the three breeding lines are in agreement with the findings of Liebenberg (2003) in an earlier study in which the combination with $U r-4$ and $U r-11$ genes provided effective rust resistance to all isolates of the bean rust from eastern and southern Africa. The selection of the breeding lines for heat tolerance under controlled environmental conditions resulted in selections with high yield stability at the three rust infected but variable temperature sites in eastern Africa and at the high temperature site in Puerto Rico.

The high correlation of pod yield response from two very distinct sites, Homabay and Puerto Rico, indicates possible broad geographical effectiveness of the breeding lines selected for heat tolerance and thus the potential for broad applicability of heat-tolerant cultivars across broad agroecological zones. This result also confirms the effectiveness of selection for hightemperature tolerance under controlled greenhouse conditions. It was also notable that HS1, which was initially selected as a heat-sensitive control, was able to yield well even under the stressful high-temperature field sites indicating that exposure to greenhouse temperatures of $32 / 27{ }^{\circ} \mathrm{C}$ (day/night) during the selection process was more stressful than the conditions at the highest temperature field sites used in this study.

The large yield reductions in 'Amy', 'Teresa', 'PV 712', and 'PV 698' that were observed at the Homabay and Puerto Rico sites relative to the Kitale site (Table 4; Fig. 5) indicate that these cultivars that are presently grown in or are targeted for production in the eastern Africa region have high sensitivity to relatively small increases in ambient temperature. This explains the current scenario in which snap bean production in the region is restricted to the cooler mid- and higher altitude regions and supports the need to improve cultivars for high temperature tolerance. The large reduction in yield of these cultivars at the 
higher temperature sites illustrates the magnitude of increase in production in warmer areas that genetic improvement for heat tolerance can bring. This observation together with the observation that there was significant rust occurrence at the hightemperature Homabay site confirms the need to combine rust resistance and heat tolerance traits in snap bean cultivars for eastern Africa.

The observation that 'Teresa', which has the $U r$-5 gene, was rust-resistant at the Kitale site and especially at the Arusha site where rust pressure was high indicating that the $U r-5$ gene is effective against many races of rust found in eastern Africa. The finding that $U r-5$ also confers resistance against many races of the bean rust may be used to enhance durability of the resistance on $U r-4$ and $U r-11$ gene combination. Crossing $U r-5$ genotypes such as 'Teresa' with genotypes having $U r-4$ and $U r-11$ would result in cultivars that pyramid $U r-4, U r-5$, and $U r-11$. These pyramided lines, carrying the Middle American resistance alleles, $U r-5$ and $U r-11$, would be particularly effective against Andean races of rust that predominate in eastern Africa.

The observation that only a proportion of 'Teresa' and 'Palati' plants had symptoms of bean rust at Homabay may further imply that the race that overcomes $U r-5$ is present at this site at relatively low frequency or that it is less aggressive in nature. Possible differences in the structure of the genetic diversity of common beans grown in the Homabay region and hence a corresponding difference in the diversity of compatible races of the bean rust pathogen may also account for this observation.

The breeding lines HT1 and HT2, which were developed and confirmed to have $U r-4$ and $U r-11$ in addition to tolerance to high temperatures, could be used to improve snap beans for the tropics and other environments where bean rust and heat stress are production constraints. The development of snap bean cultivars that combine resistance to rust and tolerance to heat stress could increase yield and quality in these areas as well as expand potential production areas and/or seasons. Adoption of rust-resistant cultivars would eliminate the use fungicides in the control of rust resulting in reduced snap bean production costs. The germplasm developed in this study is being used in crosses with snap bean cultivars currently grown in eastern Africa to develop for the region new rust-resistant and heat-tolerant cultivars with desirable yield and quality attributes.

\section{Literature Cited}

Araya, C.M., A.T. Alleyne, J.R. Steadman, K.M. Eskridge, and D.P. Coyne. 2004. Phenotypic and genotypic characterization of Uromyces appendiculatus from Phaseolus vulgaris in the Americas. Plant Dis. 88:830-836.

Asfaw, A., M.W. Blair, and C. Almekinders. 2009. Genetic diversity and population structure of common bean (Phaseolus vulgaris L.) landraces from the east African highlands. Theor. Appl. Genet. 120:1-12.

Bliss, F.A. 1980. Common bean, p. 273-284. In: Fehr, W.R. and H.H. Hadley (eds.). Hybridization of crop plants. Amer. Soc. Agron., Crop Sci. Soc. Amer., Madison, WI.

Boodley, J.W. and R. Sheldrake, Jr. 1972. Cornell peat-lite mixes for commercial plant growing. Cornell Info. Bul. 43:1-8.

Centro Internacional de Agricultura Tropical. 2006. CIAT in Africa: Snap beans for income generation by small farmers in east Africa. 30 July 2010. <http://www.CIAT.CGIAR.org.africa/pdf/highlight31. pdf $>$.

Challinor, A.T., T. Wheeler, C. Garforth, P. Craufurd, and A. Kassam. 2007. Assessing the vulnerability of food crop systems in Africa to climate change. Clim. Change 83:381-399.
Hillocks, R.J., C.S. Madata, R. Chirwa, E.M. Minja, and S. Msolla. 2006. Phaseolus bean improvement in Tanzania, 1959-2005. Euphytica 150:215-231.

Intergovernmental Panel on Climate Change. 2001. Climate change. 2001: Impacts, adaptation and vulnerability-Technical summary. 30 July 2010. <http://www.grida.no/climate/ipcc_tar/wg1/pdf/ WG1_TAR-FRONT.pdf>

Jochua, C.N., J.R. Steadman, M.I.V. Amane, and J.G. Fenton. 2004. Pathotype variation and sources of resistance to the common bean rust pathogen in southern Mozambique. Annu. Rep. Bean Improv. Coop. 47:113-114.

Kimani, P.M., H. Assefa, G. Rakotomalala, and A. Rabakoarihanta. 2002. Research on bean rust in east and central Africa: Status and future directions. Annu. Rep. Bean Improv. Coop. 45:134-135.

Liebenberg, M.M. 2003. Breeding for resistance to rust of dry bean (Phaseolus vulgaris) in South Africa. PhD diss., University of the Free State, Bloemfontein, South Africa.

Liebenberg, M.M., C.M.S. Mienie, and Z.A. Pretorius. 2006. The occurrence of rust resistance gene $U r-13$ in common bean cultivars and lines. Euphytica 150:365-386.

Markell, S.M., M.A. Pastor-Corrales, J.G. Jordahl, R.S. Lampa, F.B. Mathew, J.M. Osorno, and R.S. Goswami. 2009. Virulence of Uromyces appendiculatus to the resistance gene $U r-3$ identified in North Dakota in 2008. Annu. Rep. Bean Improv. Coop. 52:82-83.

Mbaga, M.T., J.R. Steadman, and K.M. Eskridge. 1996. Virulence patterns of Uromyces appendiculatus from different geographical areas and implications for finding durable resistance to rust in common bean. J. Phytopathol. 144:533-541.

Omae, H., A. Kumar, K. Kashiwaba, and M. Shono. 2007. Influence of temperature shift after flowering on dry matter partitioning in two cultivars of snap bean (Phaseolus vulgaris) that differ in heat tolerance. Plant Prod. Sci. 10:14-19.

Pastor-Corrales, M.A. 2001. The reaction of 19 bean rust differential cultivars to 94 races of Uromyces appendiculatus and the implication for the development of rust resistant cultivars. Annu. Rep. Bean Improv. Coop. 44:103-104.

Pastor-Corrales, M.A. 2006. Diversity of the rust pathogen and common bean guides gene deployment for development of bean cultivars with durable rust resistance. Annu. Rep. Bean Improv. Coop. 49:51-52.

Pastor-Corrales, M.A., J.D. Kelly, J.R. Steadman, D.T. Lindgren, J.R. Stavely, and D.P. Coyne. 2007. Registration of six great northern bean germplasm lines with enhanced resistance to rust and bean common mosaic and necrosis potyviruses. J. Plant Registration 1:7779.

Pastor-Corrales, M.A., E.M. Wright, S.G. Markel, H.E. Awale, J.D. Kelly, J.G. Jordahl, R.S. Lamppa, F.M. Mathew, J.M. Osorno, and R.S. Goswami. 2010. Comparing the virulence of new races of the common bean rust pathogen from Michigan and North Dakota. Annu. Rep. Bean Improv. Coop. 53:128-129.

Porch, T.G., R. Bernsten, J.C. Rosas, and M. Jahn. 2007. Climate change and the potential economic benefits of heat tolerant bean varieties for farmers in Atlántida, Honduras. J. Agr. Univ. Puerto Rico 91:133-148.

Porch, T.G., M.H. Dickson, M.C. Long, D.R. Viands, and M. Jahn. 2004. General combining ability effects for reproductive heat tolerance in snap bean. J. Agr. Univ. Puerto Rico 88:161-164.

Porch, T.G. and M. Jahn. 2001. Effects of high-temperature stress on microsporogenesis in heat-sensitive and heat-tolerant genotypes of Phaseolus vulgaris. Plant Cell Environ. 24:723-731.

Rainey, K.M. and P.D. Griffiths. 2004. Segregation of heat tolerance in five $F_{2}$ generations. Annu. Rep. Bean Improv. Coop. 47:201-202.

Rainey, K.M. and P.D. Griffiths. 2005a. Inheritance of heat tolerance during reproductive development in snap bean (Phaseolus vulgaris L.). J. Amer. Soc. Hort. Sci. 130:700-706.

Rainey, K.M. and P.D. Griffiths. 2005b. Differential response of common bean genotypes to high temperature. J. Amer. Soc. Hort. Sci. 130:18-23. 
Rainey, K.M. and P.D. Griffiths. 2005c. Diallel analysis of yield components of snap beans exposed to two temperature stress environments. Euphytica 142:43-53.

Singh, S.P. 1999. Production and utilization, p. 1-24. In: Singh, S.P. (ed.). Common bean improvement in the twenty-first century. Kluwer, Dordrecht, The Netherlands.

Stavely, J.R., G.F. Freytag, J.R. Steadman, and H.F. Schwartz. 1983. The 1983 bean rust workshop. Annu. Rep. Bean Improv. Coop. 26:4-6.

Stavely, J.R. and R.T. McMillan. 1991. Release of four market type snap bean germplasm lines, BELFLA-Rust Resistant -1, -2, -3, and -4. USDA and Florida Agr. Exp. Station. USDA Release Notice.

Stavely, J.R. and M.A. Pastor-Corrales. 1989. Rust, p. 159-194. In: Schwartz, H.F. and M.A. Pastor-Corrales (eds.). Bean production problems in the tropics. Centro Internacional de Agricultura Tropical, Cali, Colombia.

Steadman, J.R., M.A. Pastor-Corrales, and J.S. Beaver. 2002. An overview of the $3 \mathrm{rd}$ bean rust and $2 \mathrm{nd}$ bean common bacterial blight international workshops, Mar. 4-8, 2002, Pietermaritzburg, South Africa. Annu. Rep. Bean Improv. Coop. 45:120-124.

Wahid, A., S. Gelani, M. Ashraf, and M.R. Foolad. 2007. Heat tolerance in plants: An overview. Environ. Exp. Bot. 61:199-223.

Wortmann, C.S., R.A. Kirkby, C.A. Eledu, and D.J. Allen. 1998. Atlas of common bean (Phaseolus vulgaris L.) production in Africa, $\mathrm{p}$. 63-88. CIAT Pan-African bean research alliance. Vol. 133. Centro Internacional de Agricultura Tropical, Cali, Colombia.

Wright, E.M., H.E. Awale, and J.D. Kelly. 2008. Use of TRAP markers to map resistance to a new race of common bean rust in Michigan. Annu. Rep. Bean Improv. Coop. 51:210-211. 